\title{
Total Synthesis of Caprazol
}

Key Words

Sharpless asymmetric aminohydroxylation glycosylation<smiles></smiles><smiles>CCC1(CC)O[C@@H]2C(CN)O[C@@H](F)[C@@H]2O1</smiles><smiles>CN(C)C(C(=O)N(C)[C@@H](C(=O)O)C(O)C[18O])[C@H](OC1OC(CN)[C@H](O)[C@H]1O)[C@H]1OC(n2ccc(=O)[nH]c2=O)[C@H](O)[C@@H]1O</smiles>

C

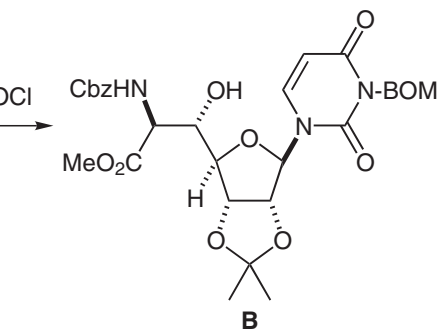

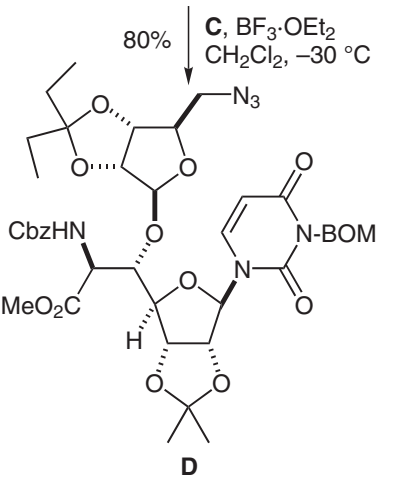

Significance: Caprazol is the core structure of the Caprazamycin antibiotics. The Caprazamycins are isolated from Streptomyces sp MK730-62F2. They inhibit Mra Y, a key enzyme in peptidoglycan synthesis in Mycobacterium tuberculosis. They have no significant toxicity to mice.
Comment: Key steps in the 18-step synthesis of Caprazol were (a) a Sharpless asymmetric aminohydroxylation reaction which converts $\mathbf{A}$ to $\mathbf{B}$; glycosylation using a 5-aminoribosyl fluoride $\mathbf{C}$; and (c) a reductive amination to create the diazepanone ring. The stereochemistry of the difficult glycosylation depended strongly on the steric bulk of the 3-pentylidene protecting group and the Lewis acid activator. With $\mathrm{BF}_{3} \cdot \mathrm{OEt}_{2}$ at $-30{ }^{\circ} \mathrm{C}$, the anomeric ratio was $\alpha: \beta=4: 96$. 